

(RESEARCH ARTiClE)

Check for updates

\title{
Increasing income and farming management: Empowering survivor farmers in reducing the impact of Covid-19
}

\author{
S Jumiyati * and I Irmawati \\ Department of Agribusiness, Faculty of Agriculture, University of Muhammadiyah of Palu 94118, Central Sulawesi, \\ Indonesia.
}

World Journal of Advanced Research and Reviews, 2021, 11(01), 221-228

Publication history: Received on 19 June 2021; revised on 27 July 2021; accepted on 29 July 2021

Article DOI: https://doi.org/10.30574/wjarr.2021.11.1.0338

\begin{abstract}
The Covid-19 pandemic had an impact on the agricultural sector in Central Sulawesi, which had previously been a victim of the earthquake, tsunami, and liquefaction that occurred on September 28, 2018. Facing this condition, the program to empower local shallot farmers in Palu, Sigi Regency, Central Sulawesi Province through the Jama'ah Tani Muhammadiyah (JATAM) group is very strategic. The income of local shallot farmers in Palu before and after the empowerment program and farm management studies during the Covid-19 pandemic was carried out using in-depth observation and interview techniques. In addition, Income Analysis was conducted to calculate the difference in farmers' income before and after empowerment. The results showed an increase in farmers' income after joining the JATAM group from an initial income of IDR. 10.304.500, - to IDR. 15,041,000,-. Furthermore, farming management, which includes aspects of land management, nurseries, planting, fertilizing, maintenance, harvesting and post-harvest to marketing and processing harvests into processed food products, namely Palu fried onions, has been carried out based on agribusiness management. Agribusiness management includes the functions of planning, organizing, implementing to monitoring. Empowerment activities consist of synergistic and comprehensive counseling, training and assistance aspects of production, marketing to agribusiness-based processing and mitigation of the COVID-19 pandemic.
\end{abstract}

Keywords: Income; Farm management; Empowerment; Covid 19

\section{Introduction}

Muhammadiyah as a social organization is committed to participating in the rehabilitation and reconstruction process in the earthquake disaster recovery in Palu City, Sigi, and Donggala Regencies [1]. An earthquake with a magnitude of 7.7 on the Richter scale, which was accompanied by liquefaction on September 29, 2018, destroyed various aspects of life, including the agricultural sector. Muhammadiyah involves internal elements, including the Muhammadiyah Disaster Management Center (MDMC), Aisyiyah, Community Empowerment Council (MPM), Lazismu, and Muhammadiyah Higher Education as a form of Muhammadiyah's seriousness in improving the welfare of the survivors of farmers [2]. The farmer empowerment program carried out in the Langgaleso area, Sigi Regency, Central Sulawesi Province through the Jama'ah Tani Muhammadiyah (JATAM) group seeks to build cooperation between Palu's local shallot farmers and the spirit of mutual cooperation in working to get back up.

Empowerment through efforts to increase farmers' income will be achieved through increased production and farm productivity. One of the efforts to increase farm production and productivity is to refer to the integration of local technology and resources that can produce a synergistic effect and high efficiency, as a vehicle for plant management and site-specific resources [3]. The principle used is to prioritize solving local problems (farmers and their land) and

\footnotetext{
${ }^{*}$ Corresponding author: S Jumiyati

Department of Agribusiness, Faculty of Agriculture, University of Muhammadiyah Palu 94118, Central Sulawesi, Indonesia.

Copyright (C) 2021 Author(s) retain the copyright of this article. This article is published under the terms of the Creative Commons Attribution Liscense 4.0.
} 
integrating plant and environmental management [4]. This goal can be achieved through activities to increase productivity, increase the economic value/profits of farming through input efficiency and conserve resources for the sustainability of the production system [5]. The average production of local Palu fried onions at the farmer level is still low at around 1-3 tons/ha [6].

The development of farm management seeks to improve a higher standard of living and is a way to achieve the ultimate goal [7]. Farm management includes: planning, organizing, implementing, and monitoring. The human dimension in this case the farmer has a very important position in implementing good management [8]. Everyone can use management principles to maintain continuous growth and progress, because management is an art. Good management must succeed in meeting the desired or predetermined goals. The key to successful farm management lies in accepting the responsibility for leadership and business decision-making through the skillful application of management principles. Farm management is unique, because farming activities are strongly influenced by the seasons, the products are quickly damaged, are part of the local community where long-term relationships between individuals are very decisive [9].

During the Covid-19 pandemic, farmers experienced limited business capital and marketing difficulties. Farmer corporations are a solution in developing and strengthening agricultural businesses to welcome the new era. Therefore, to overcome this problem, it is necessary to have a group that will help farmers in terms of marketing [10]. To avoid price fluctuations, farmers need to establish a network with direct consumers. During the pandemic, traditional marketing channels that involve middlemen to retailers are very vulnerable to causing high price spikes. For that, it is necessary to intervene other than the government in the supply chain of agricultural products [11]. The role of the community, in this case, a socio-religious organizations such as Muhammadiyah, is very strategic in making efforts to improve and empower the agricultural sector.

\section{Methods}

\subsection{Respondents Determination Method}

The location of the research was carried out in Langgaleso Village, Dolo District, Sigi Regency, Central Sulawesi Province. Determination of research locations and respondents using the Purposive Sampling method, namely local shallot farmers in Palu, who were survivors of the earthquake and liquefaction disaster on September 29, 2018. Respondents were determined as many as 20 local shallot farmers in Palu, who were members of the JATAM group.

\subsection{Data Collection and Analysis Method}

Primary data collection, which includes household income of local shallot farmers in Palu before and after the empowerment program and farm management carried out by farmers is carried out using observation techniques and in-depth interviews using a list of questions (questionnaires). While secondary data is obtained through related agencies and other relevant sources [12]. The data analysis method used is income analysis and farm management studies using qualitative descriptive analysis to describe management functions consisting of planning, organizing, directing, coordinating, and supervising. Income analysis [13] is carried out by calculating production, revenue, and farm costs, which can be written mathematically:

$$
\mathrm{I}=\mathrm{TR}-\mathrm{TC}
$$

Where:

$\begin{array}{ll}\mathrm{I} & =\text { Income } \\ \mathrm{TR} & =\text { Total Revenue (Y.Py) } \\ \mathrm{Y} & =\text { Production } \\ \mathrm{Py} & =\text { Production Price } \\ \mathrm{TC} & =\text { Total Cost }(\mathrm{FC}+\mathrm{VC}) \\ \mathrm{FC} & =\text { Fixed Cost } \\ \mathrm{VC} & =\text { Variable Cost }\end{array}$




\subsection{Research Flowchart}

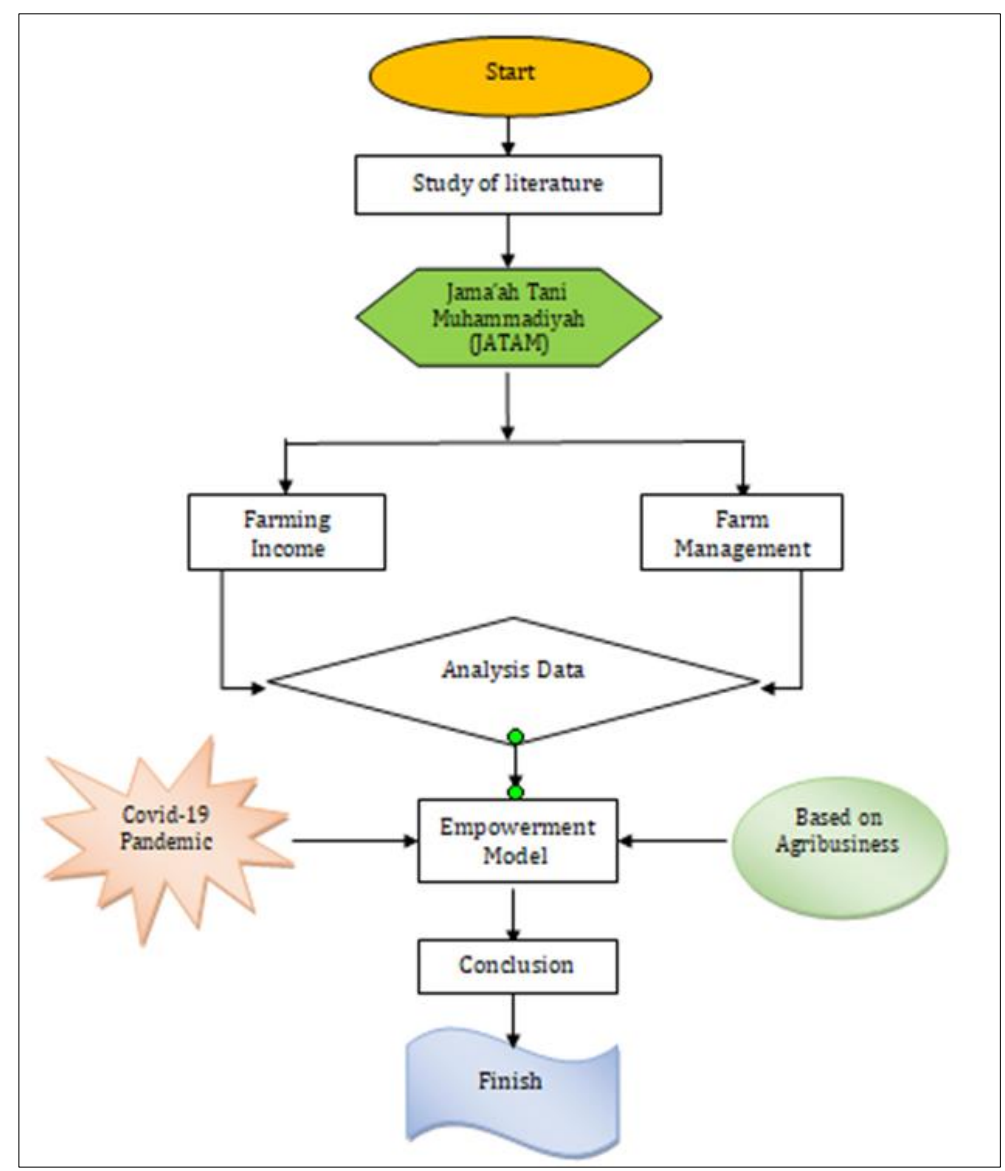

Figure 1 Research Flowchart

\section{Results and discussion}

\subsection{Farmer Profile}

Farmer profiles obtained from direct interviews with farmers include age, education level, number of dependents, farming experience, and land area owned. The profile of local shallot farmers in Palu in Langgaleso Village, Dolo District, Sigi Regency, Central Sulawesi Province is shown in Table 1 below.

Based on table 1, it can be seen that based on the dominant age classification is 24-35 years as many as 10 farmers (50.00\%). This shows that Palu's local shallot farmers are relatively young, so they have relatively high work skills, and are more innovative in managing their farming. The level of education of farmers is quite adequate, namely the high school level as many as 9 farmers (45.00\%). While the number of family dependents between 3-4 people as many as 13 respondents or $50.00 \%$. While the number of family dependents is very low, namely 0 - 1 person as many as 8 farmers $(40.00 \%)$. In addition, most of the farmers have experience in farming at the lowest criteria between 5-10 years as many as 12 farmers (60.00\%). Family dependents and farming experience owned by farmers are related to the age of farmers who are still relatively young. Based on the area of arable land, farmers have an area of arable land between $0.50-1.00$ Ha as many as 16 farmers (80.00\%). The area land arable farmers, although it is in the smallest criteria because what is cultivated is a type of vegetable crop, with an area of arable land between $0.50-1.00$ Ha owned by farmers has been able to guarantee the feasibility of farming. 
Table 1 Profile of local Palu shallot farmers in Langgaleso Village

\begin{tabular}{|c|c|c|c|c|}
\hline No & Description & Criteria & $\begin{array}{l}\text { Quantity } \\
\text { (Person) }\end{array}$ & $\begin{array}{l}\text { Percentage } \\
(\%)\end{array}$ \\
\hline \multirow[t]{4}{*}{1} & \multirow[t]{3}{*}{ Age Classification (Years) } & $24-35$ & 10 & 50,00 \\
\hline & & $36-45$ & 7 & 35,00 \\
\hline & & $46-55$ & 3 & 15,00 \\
\hline & Total & & 20 & 100,00 \\
\hline \multirow[t]{5}{*}{2} & \multirow[t]{4}{*}{ Level of education } & SD & 5 & 25,00 \\
\hline & & SLTP & 4 & 20,00 \\
\hline & & SLTA & 9 & 45,00 \\
\hline & & S1 & 2 & 10,00 \\
\hline & Total & & 20 & 100,00 \\
\hline \multirow[t]{4}{*}{3} & \multirow{3}{*}{$\begin{array}{l}\text { Family } \\
\text { (Persons) }\end{array}$} & $0-1$ & 8 & 40,00 \\
\hline & & $2-3$ & 6 & 30,00 \\
\hline & & $4-5$ & 6 & 30,00 \\
\hline & Total & & 20 & 100,00 \\
\hline \multirow[t]{4}{*}{4} & \multirow{3}{*}{$\begin{array}{l}\text { Farming } \\
\text { (Years) }\end{array}$} & $5-10$ & 12 & 60,00 \\
\hline & & $11-15$ & 4 & 20,00 \\
\hline & & $16-20$ & 4 & 20,00 \\
\hline & Total & & 20 & 100,00 \\
\hline \multirow[t]{6}{*}{5} & \multirow[t]{6}{*}{ Cultivated Land Area (Ha) } & $0,50-$ & 16 & 80,00 \\
\hline & & 1,00 & 2 & 10,00 \\
\hline & & $1,01-$ & 2 & 10,00 \\
\hline & & 1,50 & & \\
\hline & & $1,51-$ & & \\
\hline & & 2,00 & & \\
\hline & Total & & 20 & 100,00 \\
\hline
\end{tabular}

Source: Primary Data after processing, 2020.

\subsection{Farmer Income Comparison}

Farming can be said to be effective if farmers can allocate the resources they have as well as possible, and are said to be efficient if the use of these resources produces outputs that exceed inputs. Farming activities will ultimately be valued with money calculated from the value of production after deducting the costs that have been incurred, which is called farming income. The income of Palu local shallot farmers before and after joining the JATAM group in Langgaleso Village, can be seen in Table 2.

The increase in the income of local Palu shallot farmers before and after empowerment is IDR. 4,736,500 (45.97\%). Before empowerment the average production was 1,320, the cost was IDR. 13,455,500, and an income of IDR. $10,304,500$. After the empowerment, there was an increase in production of 1,452, the cost was IDR. 13,999,000, and an income of IDR. 15,041,000. The increase in income was caused by the higher income compared to the production costs incurred by the farmers. The increase in revenue was caused by an increase in production both in quantity and quality caused by the use of superior seeds. In addition to increasing production, the use of superior seeds can also increase the selling value of the product. Meanwhile, the decrease in production costs was caused by the use of organic 
fertilizers made by farmers themselves, improvement of irrigation for planting land and maintenance carried out with environmentally friendly concepts [14]. Farmers have not yet received a reasonable level of profit from the results of their operations, farmers because they can plant their commodities not planned properly optimal [15].

Table 2 Income Analysis of Palu Local Shallot Farmers in Langgaleso Village before and After Empowerment

\begin{tabular}{|l|c|c|}
\hline Description & $\begin{array}{c}\text { Before Empowerment } \\
\text { (IDR) }\end{array}$ & $\begin{array}{c}\text { After Empowerment } \\
\text { (IDR) }\end{array}$ \\
\hline Total Revenue (TR) & 1.320 & 1.452 \\
\hline Production (Y) & 18.000 & 20.000 \\
\hline Price (P) & 23.760 .000 & 29.040 .000 \\
\hline Total (Yx.P) & \multicolumn{2}{|}{} \\
\hline Total Cost (TC) & 82.500 & 82.500 \\
\hline Fixed Cost FC) & 629.000 & 629.000 \\
\hline Land Tax & 711.500 & 711.500 \\
\hline Depreciation of tools & 2.115 .000 & 1.960 .000 \\
\hline Total & 6.250 .000 & 8.425 .000 \\
\hline Variable Cost (VC) & 1.111 .000 & 602.000 \\
\hline labours & 2.673 .000 & 1.863 .000 \\
\hline Seeds & 595.000 & 437.500 \\
\hline Fertilizers & 12.744 .000 & 13.287 .500 \\
\hline Pesticides & 13.455 .500 & 13.999 .000 \\
\hline Rent of Tractor & 10.304 .500 & 15.041 .000 \\
\hline Total & Source: Primary Data after processing, 2020. \\
\hline TC = FC + VC & \\
\hline Income (I = TR - TC) & \\
\hline
\end{tabular}

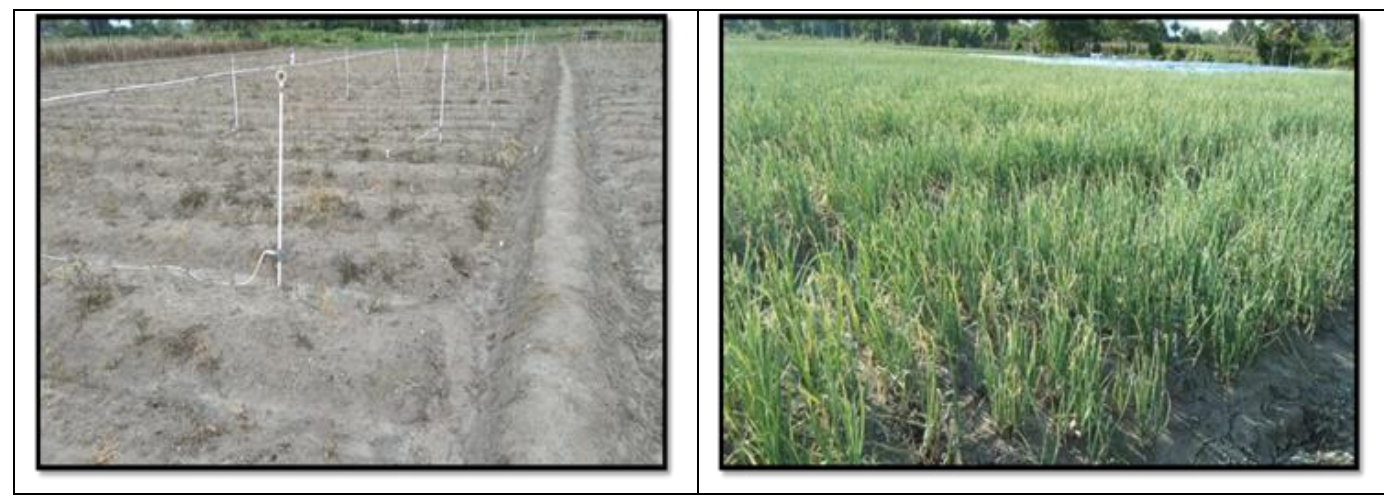

Figure 2 Land and Shallots at the Research Site

\subsection{Farm Management}

Farm management is an activity carried out by local Palu shallot farmers by implementing management functions, namely the planning function, organizing function, implementation function, and supervisory function by using available resources to increase production both quantity and quality to optimize farm income. 


\subsubsection{Planning Function}

Planning functions carried out by local Palu shallot farmers include the following activities: 1) Develop a detailed plan regarding the stages of production to be carried out, such as the amount of planned production, number of seeds and types of plant varieties, planting time, the amount of labor, the type of fertilizer and drugs used, the time of planting until the time of harvest [16]; 2) Examine the detailed plans related to the required production factors and the constraints faced by farmers; 3) Evaluating plans and compiling sequences of alternative plans related to the use of production inputs. Planning the use of capital is very important for local shallot farmers in Palu because the capital to finance their farming is very limited. Through empowerment in the form of capital education, farmers have been motivated to save by setting aside $10-30 \%$ of their total income as preparation for business capital for the next planting season. Farmers also try to take advantage of opportunities to get capital from the government through related agencies and the business world in the form of partnerships as producers of raw materials or processed onion products.

\subsubsection{Organizing Function}

The organizing function is carried out by local Palu shallot farmers in an effort to organize all production inputs to achieve the goals to be achieved. Farmers as the main mover of farming resources must have professional abilities to place workers in the right position to achieve farming effectiveness. The organizing function is also closely related to the optimal allocation of production inputs so that optimal integration of the utilization of various resources is obtained in the cultivation activities of local Palu shallot farmers. The organizing function includes the following activities: 1) Developing the organizational structure of the farm; 2) Determine the activities that must be done as well as selecting and placing workers; 3 ) Formulate forms of farming activities and how to implement them. Thus, all resources, including labor have a clear role in farming. Through the function of organizing resources, it is adjusted to the plans that have been made, both short-term plans and long-term plans [17].

\subsubsection{Implementation Function}

The implementation function is carried out by local Palu shallot farmers who are members of the JATAM group in Langgaleso Village related to the actual product, work, namely running, moving the organization according to the sequence of activities that have been planned. Implementation in farming management includes: 1) Land Processing; 2) Nursery; 3) Planting; 4) Fertilization; 5) Maintenance; 6) Harvest and Post Harvest; up to 7). Marketing and Processing. Implementation is the most decisive thing in a farming activity if you want the farming to be run successfully [18]. The implementation that will be carried out, is carried out in accordance with the plans made. Because if not, the results will not be in accordance with what is expected by the farmer. The implementation of relatively good farming management can be done according to the plan. Farmers of the JATAM group with the aim of efficiency and effectiveness of labor and capital seek to utilize labor from within the family and from the group in accordance with the stages of implementation of the on-farm and off-farm production processes.

\subsubsection{Supervision Function}

The supervisory function carried out by local Palu shallot farmers who are members of the JATAM group is the last farm management function. The supervisory function is carried out when starting land cultivation, nursery, planting, fertilizing, maintaining, harvesting, post-harvesting, marketing for processing. The supervisory function is carried out so that farming activities can run according to the plans that have been previously implemented because, with the supervision function, local shallot cultivation activities can be carried out more effectively and efficiently. Supervision of the agricultural production business includes supervision of the use of capital, the process of allocating production inputs, determining the number of workers, and work schedules in an effort to obtain maximum production. Supervision is carried out so that the planning that has been prepared can run in accordance with the expected production and the allocation of production inputs in accordance with the needs and objectives of the farm. Supervision is carried out from the planning stage production activities are completed and continued with marketing and processing activities to control if there are deviations from the plan that are considered detrimental to farming management activities [19].

\subsection{Empowerment Activities in Reducing the Impact of Covid-19}

Handling the impact of the Covid-19 pandemic by optimizing the potential of Palu's local shallot farming in Langgaleso Village. With the Large-Scale Social Restriction Policy (PSBB) and health protocols that must be adhered to, the development of technology and information can be utilized as much as possible. An alternative that can be a solution in maximizing the potential of farming is to get the needs and market the products with social media technology or other platforms that can be used as an online marketing strategy. Some strategies that can be used as an empowering model in reducing the impact of Covid-19 are as follows: 
- During a pandemic, farming activities will be constrained by health protocols, for production activities that cannot be carried out, they can be transferred to alternative activities that are safe and effective. It is hoped that farmer groups will become subjects in the implementation of farming activities for capital formation and utilization of market opportunities [20].

- Increasing cooperation with the Government, financial institutions, and all related parties to maximize the achievement of the goals and targets that have been set. The integrated collaboration will make it easier for Palu local shallot farmers to carry out production activities during the Covid-19 pandemic.

- Digitalization of marketing as an effort to market agricultural products using digital media that can reach consumers in a timely manner. Internet marketing activities generally include or revolve around those related to prospecting marketing [21].

- Increased educational activities for group members who are members of the program through online media during the pandemic and continued through offline media when the pandemic has ended. This is done through collaboration with the Information and Technology (IT) companies in the form of training and education to apply digital marketing [22].

- Seek access to productive assistance from the government during the pandemic in the form of production facilities, access to finance and technology in order to restore farmer empowerment [23]. Farmers promote Palu's local shallots as quality local products and provide added value.

\section{Conclusion}

The empowerment of local Palu shallot farmers in Langgaleso Village can increase the income of farmers who are members of the JATAM group by $45.97 \%$ of the initial income of IDR. 10,304,500,- to IDR. 15,041,000. Farm management is carried out starting from aspects of land management, nurseries, planting, fertilizing, maintenance, harvesting, and post-harvest to marketing and processing harvest processed food products, namely Palu's fried onions are in accordance with the functions of planning, organizing, implementing and supervising. Meanwhile, empowerment consists of synergistic counseling, training, and assistance aspects of production, marketing to processing to support the realization of farmer empowerment based on agribusiness management and Covid-19 mitigation through sustainable group capacity building.

\section{Compliance with ethical standards}

\section{Acknowledgments}

Thank you Majelis Diktilitbang PP. Muhammadiyah and LazisMu Pusat, for the provision of Covid-19 research grants and the guidance, so that research can be completed properly. Also, thanks to the respondent farmers who are members of the JATAM group for their cooperation and participation during the research.

\section{Disclosure of conflict of interest}

The author declares no conflict of interest.

\section{Statement of informed consent}

The author has obtained permission or approval to publish the results of interviews for academic purposes without the need to ask for writing permission from the Palu local shallot farmer group (JATAM) as the primary data source.

\section{References}

[1] Ahdiah I. Dinamika Penyintas Menjadi Relawan (Studi Kasusu pada Organisasi MDMC dalam Menangani Bencana Gempa, Tsunami dan Likuefaksi di Kota Palu). Jurnal Dialektika. 2019; 4(1): 34 - 44.

[2] Khoirudin A, Hafizd JZ. Pendampingan Operasional Bank Syariah di Masa Pandemi Covid-19. Dimasejati: Jurnal Pengabdian kepada Masyarakat. 2020; 2(2): 250 - 261.

[3] Aldillah R. Kinerja Pemanfaatan Mekanisasi Pertanian dan Implikasinya dalam Upaya Percepatan Produksi Pangan di Indonesia. Forum Penelitian Agro Ekonomi. 2016; 34(2): 163 - 177.

[4] Sari MD, Suparwoto S. Usahatani Budidaya Jagung Hibrida Varietas Bima 19-Uri di Lahan sawah Tadah Hujan Kabupaten Ogan Komering Ilir, Sumatera Selatan. AGRONITAS. 2020; 2(2): 1 - 6. 
[5] Ganda Sukmaya S, Saptana S. The Impact of Trade War toward against Indonesian Agriculture Export Products Product. E3S Web of Conferences. 2021; 232(1): 02001.

[6] Maemunah M, Adrianton A, Madauna I, Yusran Y, Mustakim M. Penerapan Teknologi Produksi Benih Bawang Merah Varietas Lembah Palu pada Kelompok Tani Bawang di Desa Simoro. MOSINTUVU: Jurnal Pengabdian pada Masyarakat. 2020; 1(1): 17 - 22.

[7] Jumiyati S, Arsyad M, Hadid A, Toknok B, Sjamsir Z. Implementation of Environmental-Economic Concepts through Farming Risk Management in Highland Vegetable Agroforestry. IOP Conference Series: Earth and Environmental Science. 2020; 575(1): 012061.

[8] Adeyonu AG, Otunaiya AO, Oyawoye EO, Okeniyi FA. Risk Perceptions and Risk Management Strategies among Poultry Farmers in South-West Nigeria. Cogent Social Sciences. 2021; 7(1).

[9] Jumiyati S, Rajindra R, Arsyad M, Pulubuhu DAT, Hadid A. Strategy of Agrarian-Forestry Crisis Management: Participation, Collaboration, and Conflict. IOP Conference Series: Earth and Environmental Science. 2019; 235(1): 012041.

[10] Jumiyati Sri. Increasing Income of Cocoa Farming through the Role of Agricultural Extension and Strengthening Institutional Capacity of Farmers. International Journal of Agriculture, Environment and Bioresearch. 2019; 4(06): $110-121$.

[11] Zuccaro G, Leone MF, Zuber SZ, Nawi MNM, Nifa FA, Zou Y, Cheung FKT. Productivity of Digital Fabrication in Construction: Cost and Time Analysis of a Robotically Built Wall. Automation in Construction. 2019; $92(1$ ): 297 311.

[12] Jumiyati S, Arsyad M, Rajindra R, Pulubuhu DAT, Hadid A. Cocoa Based Agroforestry: an Economic Perspective in Resource Scarcity Conflict Era. IOP Conference Series: Earth and Environmental Science. 2018; 157(1): 012009.

[13] Soekartawi. Agribisnis: Teori dan Aplikasinya. PT. Raja Grafindo Persada. Jakarta. 2001.

[14] Jumiyati S, Hadid A, Toknok B, Nurdin R, Paramitha TA. Climate-Smart Agriculture: Mitigation of Landslides and Increasing of Farmers' Household Food Security. IOP Conference Series: Earth and Environmental Science. 2021; 708(1): 012073.

[15] Jumiyati Sri. Poverty Level of Farmers Based on Total Income and Feasibility of Rice Farming. World Journal of Advanced Research and Reviews. 2019; 04(2): 082 - 089.

[16] Ngoune Liliane T, Shelton Charles M. Factors Affecting Yield of Crops. In Agronomy - Climate Change and Food Security. 2020.

[17] Ranjan RK, Nandi P, Chauhan Y, Iagadeesan J. Determining the yield of the crop using artificial neural network method. International Journal of Engineering and Advanced Technology. 2019; 9(1): 2959 - 2965.

[18] Jumiyati Sri, Rajindra R, Tenriawaru AN, Hadid A, Darwis D. Sustainable Land Management and Added Value Enhancement of Agricultural Superior Commodities. International Journal of Agriculture System. 2017; 5(2): 198 - 206.

[19] Khapayi M, Celliers PR. Factors Limiting and Preventing Emerging Farmers to Progress to Commercial Agricultural Farming in The King William's Town Area of The Eastern Cape Province, South Africa. South African Journal of Agricultural Extension (SAJAE). 2016; 44(1).

[20] Marchant-Forde JN, Boyle LA. COVID-19 Effects on Livestock Production: A One Welfare Issue. Frontiers in Veterinary Science. 2020; 7(1): 585787.

[21] Kersten W, Blecker T, MRC. Digitalization in Supply Chain Management and Logistics: Smart and Digital Solutions for an Industry 4.0 Environment. In Proceedings of the Hamburg International Conference of Logistics (HICL). $2017 ; 23$.

[22] Hayat AA, Keshayarzi MH, Zare S, Bazrafcan L, Rezaee R, Faghihi SA, Kojuri J. Challenges and Opportunities from the COVID-19 Pandemic in Medical Education: a Qualitative Study. BMC Medical Education. 2021; 21(247): 1 13.

[23] Fadeyi OA. Smallholder Agricultural Finance in Nigeria: Literature Review on the Research Gap. International Journal of New Technology and Research. 2018; 4(8): 26 - 33. 